Annals of Warsaw University of Life Sciences - SGGW

Land Reclamation No 38, 2007: 127-137

(Ann. Warsaw Univ. of Life Sci. - SGGW, Land Reclam. 38, 2007)

\title{
High temporal resolution monitoring in a wet grassland (Oxfordshire, UK) for estimation of evaporative loss
}

\author{
DAVID J. MOULD \\ Centre for Ecology and Hydrology, Wallingford, UK \\ Wetland Research Unit, Department of Geography, University College London, UK
}

\begin{abstract}
High temporal resolution monitoring in a wet grassland (Oxfordshire, UK) for estimation of evaporative loss. A strong diurnal regime in water levels (maximum range $10 \mathrm{~cm}$ ) was discovered by pressure transducers programmed to measure water levels at high frequency. The wetland site is a restored wet grassland floodplain in a clay basin. These water table fluctuations are used to estimate evaporative loss from the soil profile assuming constant head recovery, and compared to actual evaporation measurements derived from eddy correlation-energy budget methods. The former performed well on dry days with a strong diurnal regime, and information gained from high temporal resolution monitoring improved hydrological understanding of the wetland considerably.
\end{abstract}

Key words: high temporal resolution monitoring, evaporative loss, groundwater fluctuations, wet grassland.

\section{INTRODUCTION}

Wetlands are seasonally, periodically or permanently inundated zones forming the transition between the fully terrestrial and the fully aquatic environments. Niche and often unique ecotone habitats result, both adopting characteristics of adjoining areas and attracting specialized organisms.

Wet grasslands encompass seminatural floodplain grassland, washland, water meadows, lakeside wet grasslands, and wet grasslands with intensive water level management on drained soils (Gavin, 2001). The relatively simple botanical composition and high level of management give wet grasslands a high restorative potential in the UK, through measures such as the UK Biodiversity Action Plan (UKBAP, 2006).

Wetlands have historically been degraded, primarily through drainage and conversion to productive agricultural land. For example, three million ha of wet grassland were lost between 1937 and 1987 in England and Wales, which amounted to 39\% (Fuller, 1987).

The restoration of wetlands across Europe has gathered pace in recent years due to an increased environmental awareness of their value as habitat niches, and subsequent high biodiversity (Acreman et al., 2006). Legislation such as the European Water Framework Directive has provided impetus for wetland creation and restoration to improve the ecological status of connected water bodies (Maltby et al., 2005).

Restoration methods include increasing water levels and the conversion of intense agricultural practices to extensive grazing. Installation of foot drains is another common tool for restoring wetlands, as an assumption is often made that increasing surface water coverage raises the in-field water table. 
These foot drains ( $2.5 \mathrm{~m}$ wide, $\sim 0.4 \mathrm{~m}$ deep) are designed to irrigate in summer and drain excess water in winter, thus allowing more control of surface water. Another benefit of such foot drains is the creation of marginal habitat for breeding waders, as shallow sides help to provide water margin through a range of water depths.

This work aims to assess the efficacy of high temporal resolution monitoring undertaken in order to determine the impact of recently installed foot drains. Water level data provided is used to model evaporative loss from a wet grassland system, and compared to measured values taken on site.

\section{METHODS}

A research program, funded by the UK Government Department for the Environment, Food and Rural Affairs, has been established with the primary objective of determining the effect in wetlands of shallow foot drains. Hydrology, its effect upon invertebrate distribution (as prey for birds) and subsequent bird utilisation of foot drains for feeding and nesting, are the focus of the research. An intensive monitoring program has been established covering these aspects by the Centre for Ecology and Hydrology, with Otmoor chosen as one of the wetland monitoring sites. The current work focuses on the hydrological investigations at Otmoor.

Otmoor is 1.600 ha of agricultural land and semi-natural grazing pasture sitting on Oxford clay in southeast England (Fig. 1), $5 \mathrm{~km}$ northeast of Oxford (Oxfordshire). Otmoor lies within the floodplain of the River Ray (catchment area $290 \mathrm{~km}^{2}$; mean flow $1.83 \mathrm{~m}^{3} / \mathrm{s}$ (Marsh and Lees, 2003)), which joins the River Cherwell at Islip, and subsequently the River Thames at Oxford.

Until recently, Otmoor was productive arable farmland. Since 1997 the Royal Society for the Protection of Birds (RSPB) have restored 267 ha
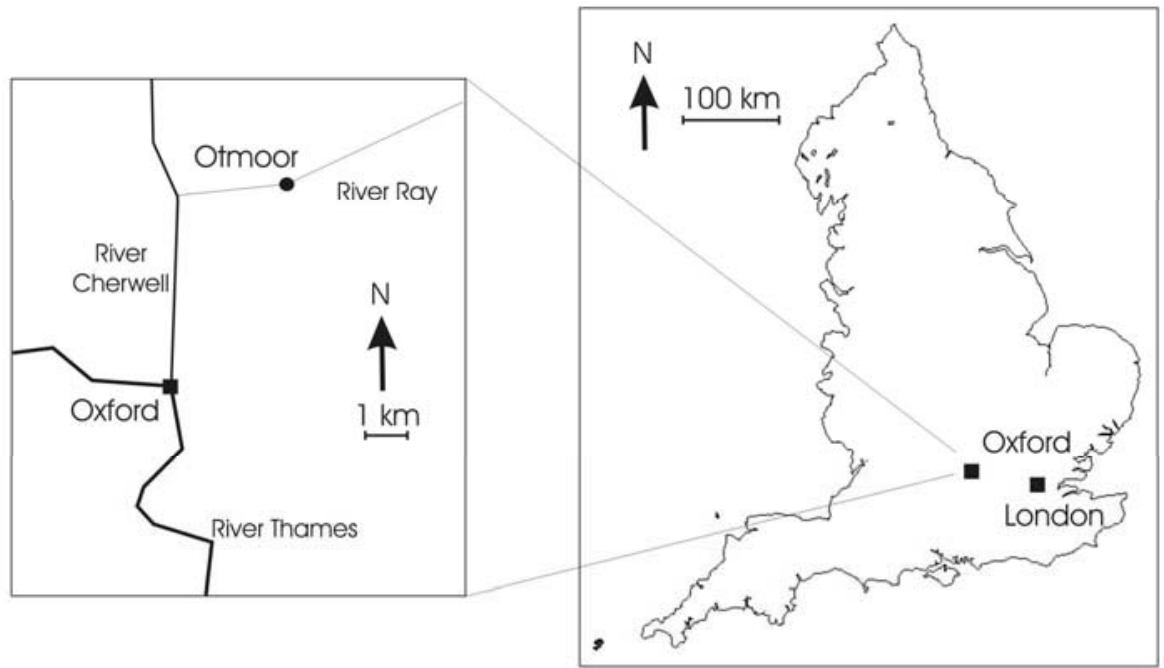

FIGURE 1. Location of Otmoor within England 
to wet grassland by increasing water levels across the site, the creation of surface foot drains and the introduction of extensive grazing. Such wet grassland provides habitat for breeding waders such as Lapwing (Vanellus vanellus) and Redshank (Tringa totanus).

Detail of the study site is shown in Figure 2. The foot drains have been placed at increasing distances apart $(5 \mathrm{~m}$, $10 \mathrm{~m}$ and $20 \mathrm{~m}$ ), in order that the effect of different distances between the foot drains be examined.

An automatic weather station (AWS, location shown on Figure 2) recorded standard meteorological variables (dry and wet bulb temperature, rainfall, wind speed and direction, net radiation). Hydrological monitoring stations, installed in transects across the site, included a dipwell to record depth to water table.

Also on site is a sonic anemometer (Solent R3, Gill Instruments, Lymington, UK). This, used in conjunction with a radiometer and soil heat flux plate, allows measurement of evapotranspiration via the eddy correlation-energy balance (ECEB) technique (van der Tol et al., 2003). This method has a high accuracy, with errors in the order of 5 to $10 \%$ (Shuttleworth, 1993), and so was taken to be a measure of actual evaporation on site.

Pressure transducers (Diver DI240, Van Essen Instruments, Delft, The Netherlands) used to record water levels were installed in a $20 \mathrm{~m}$ spacing, in order to gauge the maximum distance at which the foot drains have a notable effect on hydrology. They were placed at $1 \mathrm{~m}, 5 \mathrm{~m}$ and $10 \mathrm{~m}$ from the foot drain. A further pressure transducer was placed in the foot drain to monitor surface water levels. A pressure transducer recording barometric pressure in a dry well was used to remove the effect of atmospheric pressure from those recording water levels.

The pressure transducers were placed in piezometers. These were $2 \mathrm{~m}$ deep plastic tubes $(\varnothing 35 \mathrm{~mm})$ screened for the lower metre and unscreened for the top metre. This, and a sealing of clay surrounding the unscreened section,
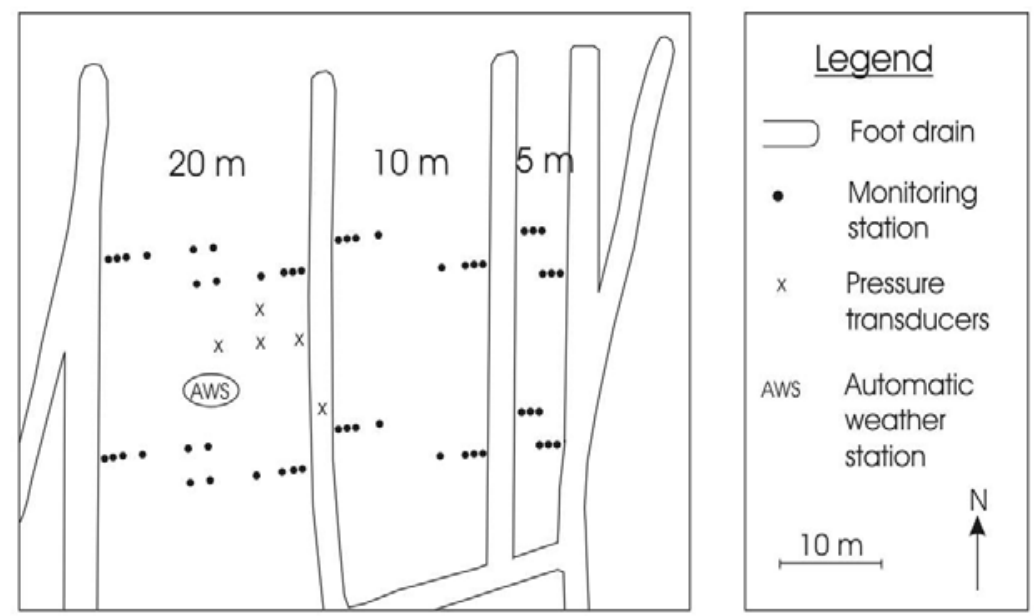

FIGURE 2. Detail of study site 
allows the effect of surface water to be excluded and only the water table level to determine the water level within the well (Fig. 3). The pressure transducers $\log$ data internally, and were calibrated during monthly site visits by measuring depth to water manually.

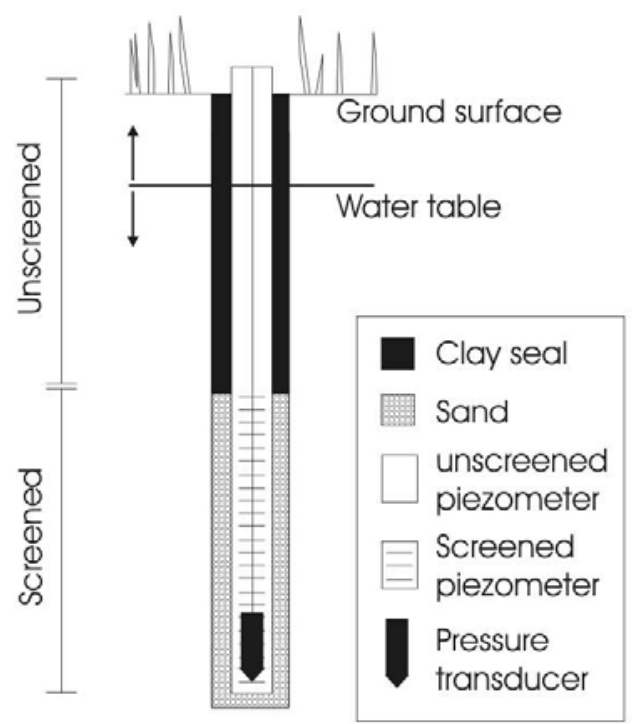

FIGURE 3. Piezometer installation

An assessment of the hydrological system operating at Otmoor was required, in order that other aspects of the research program be placed in context. Therefore the pressure transducers were programmed to record at a high frequency (sampling rate of once every ten minutes), so as to gain information on the hydrological processes operating.

It is possible to measure evaporative loss from a wetland system through interrogation of the diurnal water regime curve. Gilman (1994) developed equation (1), from White (1932), for use in peat soils in southwest England. Hays (2003) estimated water loss from Saltcedar trees which had established a similar regime in the USA, also with equation (1).

$$
E=\frac{S}{100}(24 r+s)
$$

Where $E$ is the transpiration loss from the groundwater body over the 24 hour period from midnight to midnight;

$r$-the hourly rate of recharge between the hours of midnight and 0400;

$s$ - the net fall in water table over the 24 hour period;

$S$ - the specific yield of the soil, here expressed as a percentage.

Specific yield is the ratio of the volume of water that drains from a saturated soil owing to the attraction of gravity to the total volume of the soil (Fetter, 1994). A value of $3 \%$ was used for specific yield, corresponding to typical values for clay soils stated in the literature (e.g. Fetter, 1994).

The method assumes that the recovery experienced during the hours of darkness (when plants are inactive and transpiration may be assumed to be zero) is constant throughout the day. Therefore the loss during active hours is in addition to this.

\section{RESULTS}

The surface water level in the foot drain and water table $10 \mathrm{~m}$ from the foot drain during the period from 20th May (day number 140) to 4th July (185) 2006 are shown in Figure 4, along with rainfall. It is clear that the water table falls rapidly through the early summer after heavy rain in late May. The rapid rise in surface 
water level on day 166 and shortly afterwards in the field centre was due to managed pumping of water onto the site. Such an event is similar in nature to an extreme rainfall event and has identical consequences for water levels.

The horizontal lines in Figure 4 represent the ground surface at the respective locations. During the summer months, the foot drain generally has a lower water level than at $10 \mathrm{~m}$ from the foot drain, and so acts to drain the area. The reverse is the case in the few days after a rainfall or pumping event where surface water from the foot drain is irrigating the centre of the field, with the effects visible at $10 \mathrm{~m}$ from the foot drain. This is shown after days 153 (when the site was hydrologically reisolated after a release of excess water, a situation which remained for the data collection period) and 166.

Most striking from the results shown is the identification of a strong diurnal fluctuation of water table levels, of up to $10 \mathrm{~cm}$. As the water level drops through the summer months, the diurnal fluctuation in water levels begins to weaken. This happens when water levels drop to approximately 0.70 to $0.75 \mathrm{~m}$ below the ground surface, as indicated by the $10 \mathrm{~m}$ water level in Figure 4 .

The modelled results for the period 31st May (day number 151) to 19th June
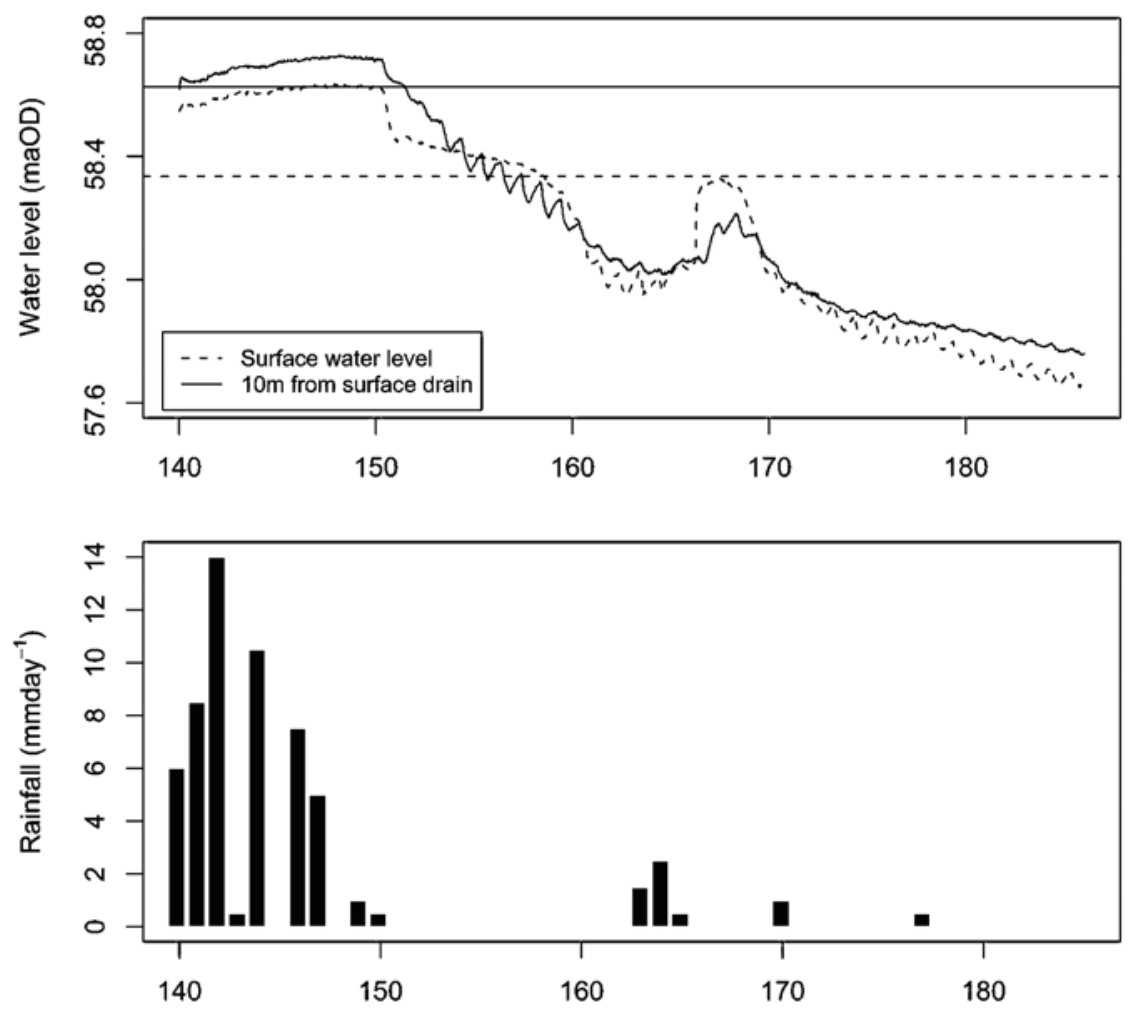

Day number 2006

FIGURE 4. Water level and rainfall data at Otmoor 
(170) are plotted in Figure 5 and compared with the observed (ECEB technique). It can be seen that evaporation estimates derived from the water table fluctuation (WTF) method follow broadly those obtained through ECEB.

It was found that this method was only successful on days of zero precipitation. Errors were larger on days when rain was recorded (e.g. days 163 and 164), and when the diurnal water level fluctuation was smaller, such as between days 160 and 163.

\section{DISCUSSION}

It has been shown that in-field water table levels are linked to the foot drains across the maximum foot drain spacing, which is at least $10 \mathrm{~m}$ from the foot drain. The foot drains were shown to be draining the field during the summer, in contrast to the planned management objectives whereby the foot drains irrigate the field, as generally there was insufficient water for this. However, the fact that irrigation to the field centre takes place when sufficient water is available after rainfall or pumping, demonstrates that having water in foot drains is effective and satisfies management objectives.

The analysis of data from pressure transducers revealed a strong diurnal fluctuation in water table levels. Although common in many more permeable soils, and especially wetland soils where evapotranspiration is not water limited (Gilman, 1994; Wetzel, 1999), this process was unexpected at Otmoor. It was assumed that the heavy clay structure of the soil profile would have a low hydraulic conductivity and impede the vertical water fluxes required for this process.

This regime is driven by transpiration through the day with head recovery taking place during the hours of vegetative inactivity. Water loss via evapotranspiration is well known to follow such a diurnal pattern, as it is driven by diurnal cycles in temperature

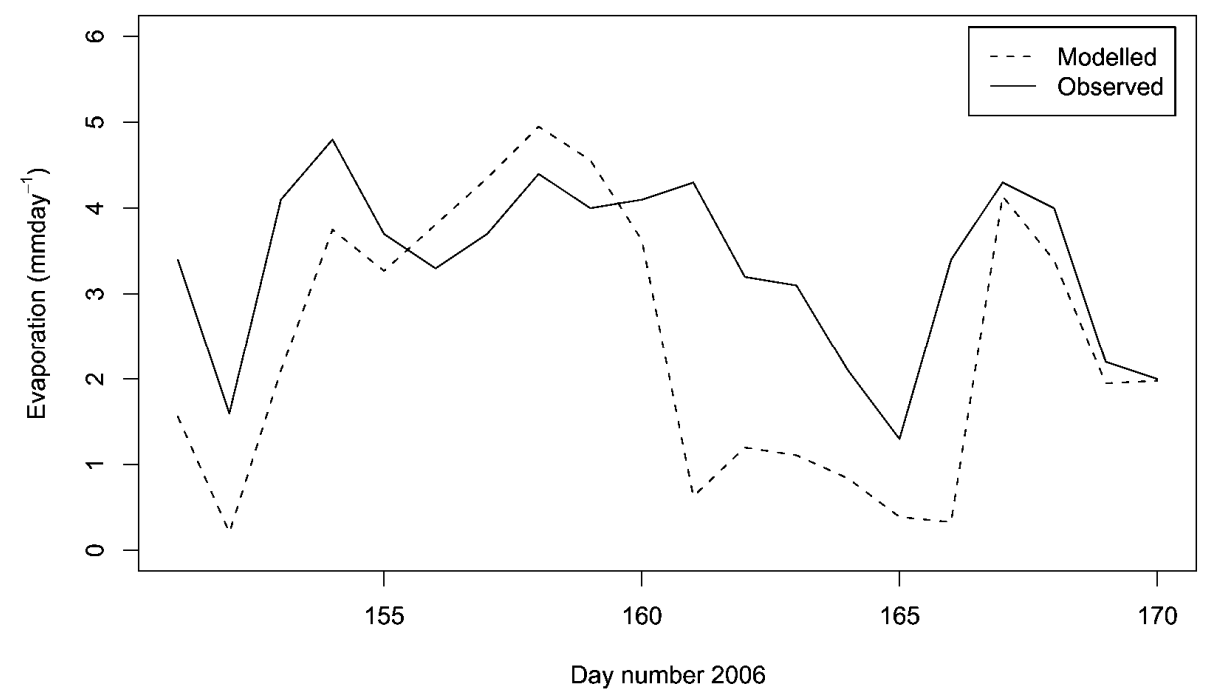

FIGURE 5. Comparison of evaporation data from WTF (modelled) and ECEB (observed) methods 
and light levels (Snyder and Boyd, 1987; Price, 1994). As evapotranspiration is a major conduit for water loss in wetland environments (Gavin, 2001), it can be inferred that this process is driving the diurnal cycle in water levels on site.

This regime is only observed when the water level is below the ground surface; above this the process occurring is open water evaporation, and any effect will be dampened by the extensive area under water. The regime also develops in the field drain water level, once the this level has dropped below that of the drain bed for the same reasons.

Also of note is the cessation of this regime once the water level has dropped below the limit at which phreatophytic plants can access the water. This level, as indicated by the $10 \mathrm{~m}$ water level in Figure 4 is about 0.70 to $0.75 \mathrm{~m}$ below the ground surface, where the regime begins to weaken in strength.

The diurnal fluctuation was present in all soil water levels recorded, and the surface water level. Together with the linkage between the foot drain and the field centre, this implies that both vertical and lateral hydraulic conductivities are greater than the low values expected from the soil profile, advocated by its high clay content. This may be due to the development of preferential flow pathways from soil cracking.

Such water table fluctuations may allow further investigation and in this case evapotranspiration has been estimated and compared to that measured by an expensive ( $₹ 20.000)$ instrument. This is only possible on days where a clear fluctuation is visible, and no precipitation has been recorded.
The results show that although the estimation of evapotranspiration is less accurate and the user would have less confidence in the values given, using analysis of water table fluctuations as a substitute may have utility where more expensive methods are unavailable.

The values for evapotranspiration calculated through the water table fluctuation method relies heavily on the value used for specific yield. Here, a typical value was taken from the literature. Improvements in accuracy may be available through determination of site specific measurements.

A localised water table has been confirmed by drilling to a depth of 4 $\mathrm{m}$; below $2.5 \mathrm{~m}$ a lack of signs of both oxidation and reduction indicates a consistently dry clay layer. It is therefore assumed that the source of water for evaporation during the summer months is the localised water table, which becomes a thinner lens as water is lost through the summer, and the generally low hydraulic conductivity of the soil would prevent any regional flow from replenishing this.

This corroborates information known on the more regional geology surrounding Otmoor. Kellaway limestone underlies a deposit of mid-Jurassic mudstone (Oxford Clay), the boundary of which lies at between 37 and $50 \mathrm{~m}$ below the surface of Otmoor. This impermeable clay supports a thin (2 to $3 \mathrm{~m}$ ) layer of alluvially reworked clay at the surface.

Pressure transducers have shown considerable utility and flexibility in the field of wetland monitoring. Whereas water levels in most wetlands may be sampled manually at a frequency of weekly at most, logging systems such as 
this allow this frequency to be increased to sub-hourly.

The increase in information this sampling rate reveals may allow the

wetland watermanager to more efficiently manage water on site. An indication of this increase in information is shown in Figure 6. Here, monthly (a), weekly Monthly (a)

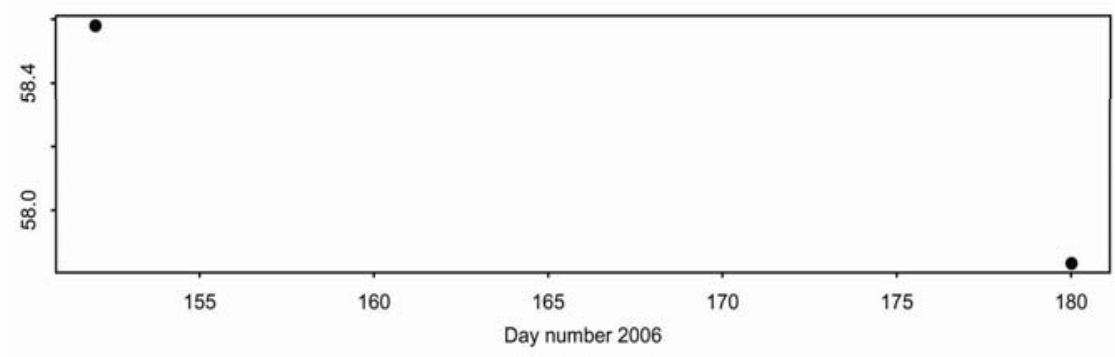

Weekly (b)

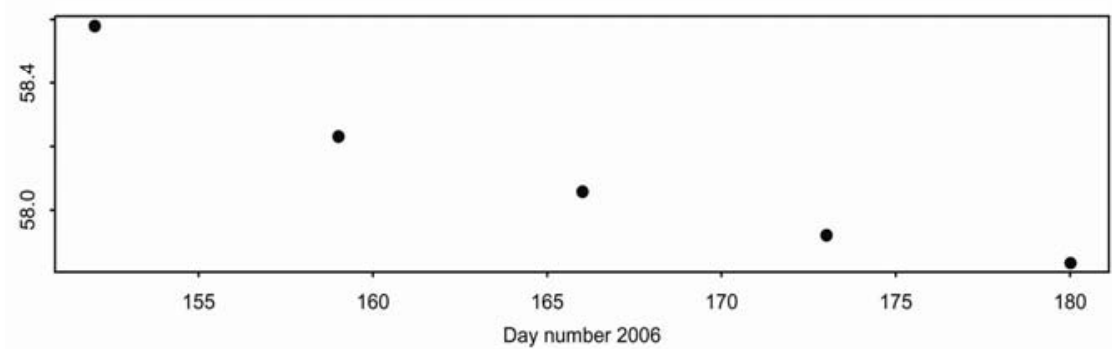

Daily (c)

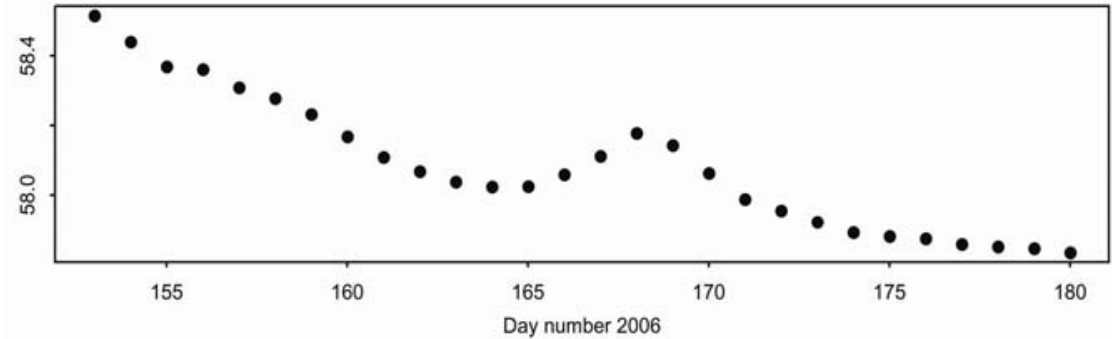

Hourly (d)

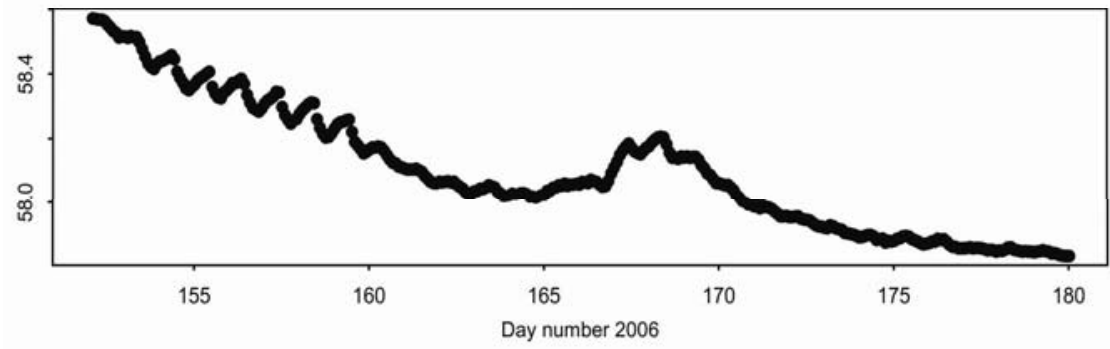

FIGURE 6. Wetland sampling rates 
(b), daily (c) and hourly (d) sample rates are shown. It is clear that this increased frequency of sampling allows a better understanding of the hydrological system on site. With a monthly sample rate it may only be determined that water levels have dropped, but any further detail will be hidden. By contrast, hourly sampling rates reveal the both the intricacies of the hydrological response to rainfall events, and the interaction of the hydrology with the vegetation on site.

\section{CONCLUSIONS}

The findings of the current work have important implications for wetland hydrology and water resources management. It has been shown that a clay soil in a wetland environment does not necessarily imply poor water movement through the soil. It should not be assumed that a heavy clay soil profile will preclude a hydrologically dynamic soil water system.

This is true both laterally, shown by the transfer of water from the foot drain to the centre of field and vice versa, and vertically, shown by diurnal water table fluctuations driven by evapotranspiration. This is despite the assumed low hydraulic conductivity of the soil profile indicated by its heavy clay structure. The importance of sound hydrological knowledge (Hollis and Thompson, 1998) of a site has been reinforced.

High temporal resolution monitoring is key to the understanding of wetland hydrology, which may be highly dynamic. Determination of the hydrological regime at the fine temporal scale may give an indication of intricate hydrological fluxes in a wetland site, which may form a substantial component of the water budget.

In the example given of Otmoor, UK, evaporation was estimated from small scale water table fluctuations identified using high temporal resolution monitoring. Calculated values were comparable with actual evaporation when conditions allowed. Evaporation has been estimated at wetland sites using this method previously (Gilman, 1994), but not in clay soils.

There is a need to investigate in more detail the hydraulic properties of the soil at Otmoor. In particular, the hydraulic conductivity indicated by this research is greater than that of clay soils in general. Similarly, the value for specific yield was estimated at 3\%. Although this fits with typical given values for clay soils (Fetter, 1994), a more detailed understanding of the value would add confidence to data analysis.

Furthermore, there is a need for further research to be undertaken both in the transpiration regime of the sward at Otmoor, as it is assumed that this is what drives the hydrological regime on site.

With increasing amounts of money being spent on wetland restoration in the UK and continental Europe, it is important that money is wisely distributed. Understanding the hydrology of a site is fundamental to determining restoration potential and subsequent management objectives. Foot drains can only irrigate the field if sufficient water is available to fill them; otherwise they act to drain any remaining higher water from the field.

This work reinforces the notion that hydrology is central to successful management and continued wetland existence (e.g. Hollis and Thompson, 1998; Haslam, 2003, Acreman et al., 2006). 
The hydrology of wetlands therefore requires a significantly improved understanding if we are to halt the loss of wetlands as described by Acreman and José (2000). High temporal resolution monitoring can add to the understanding of wetland hydrology and therefore is a tool for the wetland conservationist and manager.

\section{ACKNOWLEDGMENTS}

The author was funded by NERC (studentship number NER/S/A/2004/12085) whilst undertaking this work. Andrew Hughes (British Geological Survey, Wallingford, UK) provided data on the geology and superficial deposits of the Otmoor area. Comments from Mike Acreman, Charles Stratford and Manuel Dueńas were gratefully received.

\section{REFERENCES}

ACREMAN M.C., JOSÉ P. 2000: Wetlands. In Acreman, M.C. (Ed.). The Hydrology of the UK: A Study of Change. Routledge, London, p. 303.

ACREMAN M.C., FISHER J., STRATFORD C.J., MOULD D.J., MOUNTFORD J.O. 2007: Hydrological science and wetland restoration: some case studies from Europe, Hydrology and Earth System Sciences, Vol. 11, p. 158-169.

FETTER C.W. 1994: Applied Hydrogeology. Prentice Hall, Upper Saddle River, p. 691.

FULLER R.M. 1987: The changing extent and conservation interest of lowland grasslands in England and Wales: a review of grassland surveys 1930-1984. Biological Conservation, Vol. 39, p. 243 -253 .
GAVIN H. 2001: Hydrology of the Elmley Marshes. Unpublished Ph.D. Thesis, University of London, London, p. 364.

GILMAN K. 1994: Hydrology and Wetland Conservation. Wiley, Chichester, p. 101.

HASLAM S.M. 2003: Understanding Wetlands. Taylor and Francis, London, p. 296.

HAYS K.B. 2003: Water use by Saltcedar (Tamarix sp.) and associated vegetation on the Canadian, Colorado and Pecos Rivers, Texas. Unpublished thesis, Texas A\&M University.

HOLLIS G.E., THOMPSON J.R. 1998: Hydrological data for wetland management. Journal of CIWEM, Vol. 12, p. 9-17.

PRICE J.S. 1994: Evaporation from a lakeshore Typha marsh on Lake Ontario. Aquatic Botany, Vol. 48, p. 261-272.

MALTBY E., SGOURIDIS F., NEGRÉL PH., PETELET-GIRAUD, E., (Eds.) 2005: Eurowet, Integration of European Wetland Research in Sustainable Management of the Water Cycle. Final Report, Volume 3 (Technical Guidance).

MARSH T.J., LEES M.L. (Eds.) 2003: Hydrological Data UK: Hydrometric register and Statistics 1996-2000. Centre for Ecology and Hydrology, Wallingford, p. 208.

SHUTTLEWORTH W.J. 1993: Evaporation. In Maidment, D.R. (Ed.), Handbook of Hydrology. McGraw-Hill, New York.

SNYDER R.L., BOYD C.E. 1987: Evapotranspiration by Eichhornia crassipes (Mart.) Solms and Typha latifolia L. Aquatic Botany, Vol. 27, p. 217-227.

VAN DER TOL C., GASH J.H.C., GRANT S.J., MCNEIL D.D., ROBINSON M. 2003: Average wet canopy evaporation for a Sitka spruce forest derived using the eddy correlation-energy balance technique. Journal of Hydrology, Vol. 276, p. 12-19.

UKBAP 2006: www.ukbap.org.uk. Accessed 10/02/2006.

WETZEL R.G. 1999: Plants and water in and adjacent to lakes. In Baird, A.J. and Wilby, R.L., Eco-Hydrology: Plants and Water 
in Terrestrial and Aquatic Environments. Routledge, London, p. 269-199.

WHITE W.N. 1932: A method of estimating groundwater supplies based on discharge by plants and evaporation from soil. US Geological Survey Water Supply Paper 659, p. 1-106.

Streszczenie: Zastosowanie monitoringu wysokiej częstotliwości do określenia strat $w$ wyniku parowania z terenu lak wilgotnych (Oxfordshire, Wielka Brytania). Wyraźny dzienny reżim zmian położenia zwierciadła wody (maksymalna rozpiętość zmian $10 \mathrm{~cm}$ ) został zaobserwowany przy pomocy przetworników ciśnieniowych zaprogramowanych do pomiaru zmian położenia zwierciadła wody z wysoką częstotliwością. Monitoring tych zmian położenia zwierciadła wody prowadzony był na obszarze zrekultywowanych mokradeł o charakterze wilgotnych łąk znajdującym się na równinie zalewowej w zlewni o podłożu gliniastym. Zaobserwowane wielkości zmian położenia zwierciadła wody zostały wykorzystane do określenia wielkości strat $\mathrm{w}$ wyniku parowania z profilu glebowego, przy założeniu stałej wielkości zasilania poziomu wód gruntowych w wodę, oraz do porównania $\mathrm{z}$ wielkościami parowania rzeczywistego obliczonymi na podstawie bilansu cieplnego metodą korelacji pulsacji. Zastosowana metoda dała poprawne wyniki, szczególnie w przypadku dni bez opadu z wyraźnym dziennym reżimem zmian położenia zwierciadła wody, a zebrane $\mathrm{w}$ wyniku zastosowania monitoringu wysokiej częstotliwości obserwacje oraz otrzymane dane przyczyniły się znacząco do zrozumienia hydrologicznego funkcjonowania analizowanego obszaru mokradłowego.

\section{MS. received November 2007}

\section{Author's address:}

Centre for Ecology and Hydrology, Maclean Building, Crowmarsh Gifford, Wallingford, OX10 8BB, UK.

damo@ceh.ac.uk

Wetland Research Unit, Department of Geography, University College London, Pearson Building, Gower Street, London, WC1E 6BT, UK 